Zeszyty Naukowe Szkoły Głównej Gospodarstwa Wiejskiego

Ekonomika i Organizacja Gospodarki Żywnościowej nr 108, 2014: 79-88

Marek Kuźmicki, Monika Łęska

Wydział Nauk Ekonomicznych i Technicznych

Państwowa Szkoła Wyższa im. Papieża Jana Pawła II w Białej Podlaskiej

\title{
Uwarunkowania rozwoju przedsiębiorstw noclegowych i gastronomicznych w województwie lubelskim
}

\section{Wstęp}

Przedsiębiorczość jest kluczowym czynnikiem wzrostu gospodarczego, poprawy konkurencyjności gospodarki, tworzenia nowych miejsc pracy, wzrostu dobrobytu społeczności lokalnych i regionalnych [Lichniak (red.) 2011, s. 11].

Bardzo ważna w przypadku wszystkich przedsiębiorców jest umiejętność dostrzegania i wykorzystywania szans wynikających z otoczenia przedsiębiorstw. W tej sytuacji należy uznać za istotne badania nad uwarunkowaniami przedsiębiorczości, w tym przedsiębiorczości indywidualnej, związanej z działalnością prowadzoną na własny rachunek, samozatrudnieniem, bardzo małymi i małymi przedsiębiorstwami. Wiele podmiotów prowadzi działalność gospodarczą w tych formach na rynku turystycznym. Do najważniejszych należy tu zaliczyć obiekty noclegowe oraz zakłady i punkty gastronomiczne. Mikroprzedsiębiorcy z rynku turystycznego pełnią ważną rolę w ożywianiu lokalnej gospodarki, co jest istotne z perspektywy mieszkańców obszarów, na których prowadzona jest działalność gospodarcza. Aktywność mikroprzedsiębiorców może częściowo niwelować problemy bezrobocia na poziomie lokalnym. Rozwój mikroprzedsiębiorstw działających na rynku turystycznym przynosi także korzyści dla samorządów lokalnych - wpływy z turystki zasilają ich budżet [Grzegorzewska-Mischka 2009, s. 90].

Niestety przedsiębiorstwa świadczące usługi turystyczne napotykają na różne bariery, które utrudniają ich powstawanie i rozwój, a często prowadzą do bankructw. Opisana sytuacja może wynikać z faktu, że współczesne uwarunkowania funkcjonowania przedsiębiorstw cechuje dynamizm otoczenia oraz wieloaspek- 
towość makro- i mikrootoczenia, a także złożoność czynników i procesów wewnętrznych w przedsiębiorstwie. Sukces prowadzonej działalności gospodarczej na rynku turystycznym wiąże się nieodzownie z umiejętnością dostrzegania i wykorzystywania przez przedsiębiorców okazji wynikających z otoczenia instytucjonalno-systemowego ${ }^{1}$.

\section{Cel i metodyka badań}

Celem opracowania jest ocena obecnego wpływu otoczenia instytucjonalno-systemowego na rozwój ${ }^{2}$ przedsiębiorstw świadczących usługi noclegowe i gastronomiczne na terenie województwa lubelskiego. Artykuł jest także próbą określenia pożądanych przez właścicieli obiektów noclegowych oraz zakładów i punktów gastronomicznych kierunków zmian otoczenia instytucjonalno-systemowego w przyszłości.

W celu określenia próby badawczej na obszarze województwa lubelskiego, podzielono 4 powiaty grodzkie i 20 powiatów ziemskich na cztery zróżnicowane względem siebie grupy. Do podziału wykorzystano analizę skupień metodą k-średnich (Quick Cluster). Podstawą do ustalenia skupień (grup powiatów) było wykorzystanie wskaźników charakteryzujących ilościowy rozwój bazy noclegowej i gastronomicznej oraz wykorzystanie bazy noclegowej analizowanego obszaru. Powiaty zaliczone do tego samego obszaru (skupienia) są do siebie podobne pod względem stopnia rozwoju i wykorzystania bazy noclegowej, a także rozwoju bazy gastronomicznej. Obszar badań został podzielony na: obszar 1 - miasta: Lublin, Zamość, obszar 2 - miasta: Biała Podlaska, Chełm, ob-

\footnotetext{
${ }^{1}$ Otoczenie systemowe stanowią rynkowe mechanizmy regulujące funkcjonowanie gospodarki, polityka społeczno-gospodarcza państwa oraz kształtujące ją czynniki formalno-prawne. Otoczenie instytucjonalne tworzą instytucje i organizacje kształtujące warunki funkcjonowania przedsiębiorstw na szczeblu regionalnym i (lub) lokalnym; M. Angowski, 2005: Wplyw otoczenia na rozwój sektora małych i średnich przedsiębiorstw na obszarach wiejskich, Wydawnictwo Akademii Rolniczej w Lublinie, Lublin, s. 15.

Wśród instytucji funkcjonujących w otoczeniu przedsiębiorstw można wyróżnić: instytucje administracji państwowej i samorządowej, banki, instytucje informacyjno-szkoleniowe, instytucje promocyjno-handlowe, izby i stowarzyszenia gospodarcze, centra wspierania biznesu i inkubatory przedsiębiorczości, agencje i fundacje rozwoju regionalnego i lokalnego; G. Sobczyk (red.), Funkcjonowanie matych firm $w$ warunkach zmian systemowych, Wydawnictwo Uniwersytetu Marii Curie-Skłodowskiej w Lublinie, Lublin, s. 11.

${ }^{2}$ Pod pojęciem rozwoju przedsiębiorstw rozumiano wszelkiego rodzaju zmiany dokonujące się w przedsiębiorstwach, powodujące poprawę ich efektywności działania i pozycji rynkowej. Za mierniki rozwoju przedsiębiorstw przyjęto: uzyskiwany wynik finansowy, wskaźnik rentowności sprzedaży, dynamikę przychodów ze sprzedaży, płynność finansową, wartość posiadanych aktywów, poziom zatrudnienia, aktywność inwestycyjną.
} 
szar 3 - powiaty: janowski, łukowski, opolski, parczewski, tomaszowski, obszar 4 - powiaty: puławski, włodawski. Próba badawcza wyłoniona do dalszych badań empirycznych została ustalona przy wykorzystaniu metody doboru losowego dwustopniowego. Pierwszy stopień doboru losowego był związany z określeniem obszaru badań. Za podstawową jednostkę przyjęto obszar powiatu, gdyż na tym poziomie terytorialnym były dostępne dane statystyczne dotyczące bazy noclegowej i gastronomicznej, niezbędne do analizy. Drugi stopień doboru losowego jednostek do próby badawczej był związany z losowaniem konkretnych podmiotów gospodarczych w układzie rodzajowym i przestrzennym. Badaniu poddano 317 podmiotów gospodarczych, w tym 24 świadczące usługi noclegowe, 46 świadczących usługi noclegowe i gastronomiczne oraz 247 świadczących usługi gastronomiczne. W próbie badawczej znalazły się hotele, motele, inne obiekty hotelowe ${ }^{3}$, ośrodki wczasowe, ośrodki szkoleniowo-wypoczynkowe, ośrodki rekreacyjno-sportowe, schroniska młodzieżowe, szkolne schroniska młodzieżowe, restauracje, bary ${ }^{4}$, stołówki i punkty gastronomiczne ${ }^{5}$.

Badanie metodą wspomaganego komputerowo wywiadu CAWI (ang. Computer-Assisted Web Interview) zrealizowano w kwietniu i maju 2013 roku.

\section{Wyniki badań}

Przedsiębiorcy w czasie badań oceniali wpływ istniejących uwarunkowań instytucjonalno-systemowych na możliwości rozwoju prowadzonej działalności gospodarczej. Prawie połowa respondentów $-48,10 \%$ uznała funkcjonujący system podatkowy ${ }^{6}$ za niesprzyjający. Jeszcze gorzej wspomniany czynnik oceniło $18,35 \%$ badanych. Zaskakujący może wydać się fakt, że tylko 35,76\% badanych

\footnotetext{
${ }^{3}$ Obiekt noclegowy, podzielony na pokoje, podlegający jednemu zarządowi, świadczący pewne usługi, w tym przynajmniej codzienne sprzątanie pokoi, słanie łóżek i mycie urządzeń sanitarnych (np. obiekt spełniający zadania hotelu, motelu lub pensjonatu, któremu nie została nadana kategoria); http://www.stat.gov.pl/gus/definicje_PLK_HTML.htm?id=POJ-4165.htm (data dostępu: 16.03.2014).

${ }^{4}$ Jadłodajnia, bar uniwersalny, przekąskowy, mleczny, kawowy, restauracyjny (bistro) i szybkiej obsługi, pizzeria, kawiarnia, herbaciarnia, winiarnia, piwiarnia, pub.

${ }^{5}$ Smażalnia, lodziarnia, pijalnia, bufet, przyczepa gastronomiczna, punkt małej gastronomii „,kurczak z rożna".

${ }^{6}$ System podatkowy - ogół podatków pobieranych w danym państwie, tworzących zarówno pod względem prawnym, jak i ekonomicznym logiczną całość. System podatkowy zawiera określenie przedmiotu i podstawy opodatkowania, stawek i skal podatkowych oraz elementów korygujących wymiar podatku (ulg, zwolnień, zwyżek).
} 
uznało dostępność kapitału ${ }^{7}$ za czynnik niesprzyjający rozwojowi swoich mikroprzedsiębiorstw. Dostępność kapitału ponad połowa przedsiębiorców oceniła jako czynnik o umiarkowanym wpływie na analizowane zjawisko. Zdecydowanie większy odsetek badanych negatywnie ocenił politykę rządu ${ }^{8}(51,58 \%)$ niż samorządów ${ }^{9}(19,94 \%)$ w kontekście tworzenia prorozwojowych warunków na rynku usług noclegowych i gastronomicznych. Szczegółowe wyniki badań przedstawia tabela 1 .

Czynniki otoczenia instytucjonalno-systemowego w trakcie badania zostały poddane przez respondentów ocenie w skali $1-5$, gdzie 1 oznaczało czynnik zdecydowanie niesprzyjający, a 5 - czynnik zdecydowanie sprzyjający. Niestety wszystkie uwarunkowania oceniono negatywnie bądź umiarkowanie. Respondenci najbardziej krytycznie odnieśli się do realizowanej polityki rządu - 2,13

\section{Tabela 1}

Ocena obecnego wpływu czynników związanych z otoczeniem instytucjonalno-systemowym na rozwój przedsiębiorstw świadczących usługi noclegowe i gastronomiczne - struktura odpowiedzi [\%]

\begin{tabular}{|l|c|c|c|c|c|}
\hline \multirow{2}{*}{$\begin{array}{l}\text { Czynniki wpływajace na rozwój } \\
\text { przedsiębiorstw świadczących } \\
\text { usługi noclegowe i gastronomiczne }\end{array}$} & $\begin{array}{c}\text { Wdecy- } \\
\text { dowanie } \\
\text { niesprzy- } \\
\text { jający }\end{array}$ & $\begin{array}{c}\text { niesprzy- } \\
\text { jający }\end{array}$ & $\begin{array}{c}\text { ani sprzy- } \\
\text { jajacy, ani } \\
\text { niesprzy- } \\
\text { jający }\end{array}$ & $\begin{array}{c}\text { sprzyja- } \\
\text { jacy }\end{array}$ & $\begin{array}{c}\text { zdecy- } \\
\text { dowanie } \\
\text { sprzyja- } \\
\text { jący }\end{array}$ \\
\hline System podatkowy & 18,35 & 48,10 & 29,11 & 4,44 & 0,00 \\
\hline Dostępność kapitału & 6,01 & 35,76 & 51,90 & 6,33 & 0,00 \\
\hline Odpowiednia polityka rządu & 18,04 & 51,58 & 29,75 & 0,63 & 0,00 \\
\hline Odpowiednia polityka samorządu & 10,13 & 19,94 & 69,30 & 0,63 & 0,00 \\
\hline Promocja gminy, powiatu & 11,08 & 10,12 & 54,43 & 24,05 & 0,32 \\
\hline Programy pomocowe UE & 4,74 & 3,80 & 58,23 & 30,70 & 2,53 \\
\hline $\begin{array}{l}\text { Pomoc organizacji wspierajacych } \\
\text { rozwój turystyki i przedsiębiorczości }\end{array}$ & 4,23 & 1,27 & 60,64 & 31,96 & 1,90 \\
\hline
\end{tabular}

Źródło: Opracowanie własne na podstawie badań ankietowych.

\footnotetext{
${ }^{7}$ Dostępność kapitału - możliwość i łatwość pozyskania kapitału z zewnętrznych źródeł finansowania, która jest uzależniona od warunków oferowanych przez instytucje finansowe, tj. przede wszystkim od wysokości stopy procentowej oraz prowizji za świadczone usługi finansowe, skomplikowanych procedur, wymaganych zabezpieczeń.

${ }^{8}$ Polityka rządu obejmuje głównie tworzenie uregulowań systemowych i strategii społeczno-gospodarczych wspierających rozwój przedsiębiorczości i turystyki oraz stymulujących swobodny rozwój przedsiębiorstw.

${ }^{9}$ Polityka samorządu związana jest z ujmowaniem w strategiach rozwoju społeczno-gospodarczego jednostek samorządowych priorytetów dotyczących rozwoju turystyki i przedsiębiorczości, a także wspieraniem lokalnych, turystycznych podmiotów gospodarczych w zakresie określonym $\mathrm{w}$ tych dokumentach planistycznych oraz $\mathrm{w}$ obszarach wynikających z ustawodawstwa.
} 
punktu. Należy zauważyć, że czynnik został istotnie wyżej oceniony przez przedsiębiorców funkcjonujących na terenie Lublina i Zamościa w porównaniu do przedsiębiorców z innych powiatów. Duże utrudnienie w prowadzeniu działalności gospodarczej stanowi obecnie funkcjonujący system podatkowy $-2,20$ punktu. Został on szczególnie nisko oceniony przez respondentów z powiatów ziemskich. Przedsiębiorcy nie są zadowoleni z realizowanej polityki przez samorządy - 2,60 punktu oraz rozwiązań warunkujących możliwość i łatwość pozyskania kapitału na rozwój działalności gospodarczej - 2,59 punktu. Według statystycznych danych źródłowych, mikroprzedsiębiorstwa oraz małe i średnie przedsiębiorstwa finansują swoją działalność przede wszystkim opierając się na funduszach własnych, ponieważ dostępność kapitału obcego dla tego rodzaju podmiotów gospodarczych jest ograniczona [Drab-Kurowska, Sokół 2010, s. 105]. Taki stan rzeczy potwierdziły badania własne autora. Trudno natomiast zgodzić się ze stwierdzeniem, że brak dostępności do źródeł finansowania jest główną barierą prowadzenia i rozwoju firm [Walica 2004, s. 82]. Wyniki badań prezentuje tabela 2.

Konsekwencją niezadowolenia przedsiębiorców z istniejących obecnie instytucjonalno-systemowych uwarunkowań rozwoju działalności gospodarczej

\section{Tabela 2}

Ocena obecnego wpływu czynników związanych z otoczeniem instytucjonalno-systemowym na rozwój przedsiębiorstw świadczących usługi noclegowe i gastronomiczne

\begin{tabular}{|l|c|c|c|c|c|}
\hline \multirow{2}{*}{$\begin{array}{l}\text { Czynniki wpływające na rozwój } \\
\text { przedsiębiorstw świadczących usługi } \\
\text { noclegowe i gastronomiczne }\end{array}$} & \multicolumn{4}{|c|}{ Obszar } & \multirow{2}{*}{ Ogół } \\
\cline { 2 - 5 } & 1 & 2 & 3 & 4 & \\
\hline System podatkowy & $2,58^{\mathrm{a}, \mathrm{b}}$ & 2,41 & $2,01^{\mathrm{a}}$ & $2,14^{\mathrm{b}}$ & 2,20 \\
\hline Dostępność kapitału & $2,76^{\mathrm{a}}$ & 2,86 & $2,48^{\mathrm{a}}$ & 2,55 & 2,59 \\
\hline Odpowiednia polityka rządu & $2,50^{\mathrm{a}, \mathrm{b}, \mathrm{c}}$ & $1,86^{\mathrm{a}}$ & $2,05^{\mathrm{b}}$ & $1,96^{\mathrm{c}}$ & 2,13 \\
\hline Odpowiednia polityka samorządu & 2,59 & 2,55 & 2,63 & 2,55 & 2,60 \\
\hline Promocja gminy, powiatu & $2,68^{\mathrm{a}}$ & $2,59^{\mathrm{b}}$ & $3,05^{\mathrm{a}, \mathrm{b}}$ & 3,00 & 2,92 \\
\hline Programy pomocowe UE & 3,16 & 3,18 & 3,26 & 3,24 & 3,22 \\
\hline $\begin{array}{l}\text { Pomoc organizacji wspierajacych } \\
\text { rozwój turystyki i przedsiębiorczości }\end{array}$ & $3,00^{\mathrm{a}, \mathrm{b}}$ & 3,23 & $3,35^{\mathrm{a}}$ & $3,43^{\mathrm{b}}$ & 3,27 \\
\hline
\end{tabular}

a,b,c - wskazuje na istotną różnicę pomiędzy daną parą średnich $(p<0,05)$.

Oznaczenia: obszar 1 - miasta: Lublin, Zamość; obszar 2 - miasta: Biała Podlaska, Chełm; obszar 3 - powiaty: janowski, łukowski, opolski, parczewski, tomaszowski; obszar 4 - powiaty: puławski, włodawski.

Liczby odpowiadaja wartościom skali 1-5, gdzie 1 - czynnik zdecydowanie niesprzyjający, 5 - czynnik zdecydowanie sprzyjający.

Źródło: Opracowanie własne na podstawie badań ankietowych. 
na rynku usług noclegowych i gastronomicznych jest prawie powszechna chęć dokonania zmian $\mathrm{w}$ tej materii. Największy odsetek badanych deklaruje potrzebę zmiany aktualnej polityki rządu (59,94\% w stopniu znacznym i 22,40\% w stopniu bardzo znacznym), która w sposób niedostateczny stymuluje swobodny rozwój przedsiębiorczości. Istnieje także dość powszechne przekonanie o potrzebie zmiany funkcjonującego systemu podatkowego. Za takim krokiem w sposób zdecydowany opowiada się $58,99 \%$, a w sposób bardzo zdecydowany $21,45 \%$ respondentów. Szczegółowe wyniki badań przedstawia tabela 3.

Właściciele obiektów noclegowych oraz zakładów i punktów gastronomicznych z województwa lubelskiego ocenili potrzebę zmian uwarunkowań otoczenia instytucjonalno-systemowego w skali 1-5, gdzie 1 oznaczało brak potrzeby zmiany, a 5 bardzo dużą potrzebę zmiany. W opinii respondentów szczególnych zmian wymaga aktualna polityka rządu $-4,03$ punktu, a więc rozwiązania o charakterze systemowym. Wyniki badań autora potwierdzają opinie innych badaczy. Stworzenie odpowiedniego systemu prawnego jest jednym z podstawowych elementów umożliwiających prawidłowe funkcjonowanie wszystkich przedsiębiorstw. Obecne przepisy, choć często nowelizowane, charakteryzują się, niestety, niskim poziomem legislacji (są niezrozumiałe i skomplikowane), co stanowi jeden z częściej wymienianych czynników hamujących rozwój przedsiębiorczości. Negatywnym aspektem związanym z obowiązującym prawem jest również

\section{Tabela 3}

Ocena potrzeby zmian czynników związanych z otoczeniem instytucjonalno-systemowym wpływających na rozwój przedsiębiorstw świadczących usługi noclegowe i gastronomiczne - struktura odpowiedzi [\%]

\begin{tabular}{|l|c|c|c|c|c|}
\hline \multirow{2}{*}{$\begin{array}{l}\text { Czynniki wpływające na rozwój } \\
\text { przedsiębiorstw świadczących usługi } \\
\text { noclegowe i gastronomiczne }\end{array}$} & \multicolumn{5}{|c|}{ Potrzeba zmiany } \\
\cline { 2 - 6 } & brak & mała & $\begin{array}{c}\text { ani } \\
\text { mała, } \\
\text { ani } \\
\text { duża }\end{array}$ & duża & $\begin{array}{c}\text { bardzo } \\
\text { duża }\end{array}$ \\
\hline System podatkowy & 0,95 & 0,95 & 17,66 & 58,99 & 21,45 \\
\hline Dostępność kapitału & 0,31 & 0,31 & 36,59 & 50,49 & 12,30 \\
\hline Odpowiednia polityka rządu & 0,31 & 0,63 & 16,72 & 59,94 & 22,40 \\
\hline Odpowiednia polityka samorządu & 0,31 & 0,31 & 52,05 & 39,76 & 7,57 \\
\hline Promocja gminy, powiatu & 2,84 & 0,63 & 65,30 & 26,18 & 5,05 \\
\hline Programy pomocowe UE & 18,30 & 10,09 & 53,31 & 14,51 & 3,79 \\
\hline $\begin{array}{l}\text { Pomoc organizacji wspierających rozwój tury- } \\
\text { styki i przedsiębiorczości }\end{array}$ & 9,46 & 3,48 & 62,46 & 20,82 & 3,78 \\
\hline
\end{tabular}

Źródło: Opracowanie własne na podstawie badań ankietowych. 
częstotliwość wprowadzanych zmian, co powoduje, że właściciele menedżerowie zmuszeni są do ich stałego śledzenia [Drab-Kurowska, A. Sokół 2010, s. 105-107]. Przedsiębiorcy mają także silne przeświadczenie o konieczności zmiany funkcjonującego systemu podatkowego, który w znaczący sposób wpływa ujemnie na uzyskiwany przez nich wynik finansowy netto - 3,99 punktu. Wyniki badań utwierdzają $\mathrm{w}$ przekonaniu, że głównym problemem w prowadzeniu działalności gospodarczej na niewielką skalę jest wysokość podatków, a także ich różnorodność. Badani w umiarkowany sposób odnoszą się do zmian oferowanych przez Unię Europejską programów pomocowych - 2,75 punktu oraz działań pomocowych organizacji wspierających rozwój turystyki i przedsiębiorczości - 3,06 punktu, co wskazuje na stosunkowo korzystną ocenę sytuacji w tym aspekcie. Szczegółowe wyniki badań przedstawia tabela 4.

\section{Tabela 4}

Ocena potrzeby zmian czynników związanych z otoczeniem instytucjonalno-systemowym wpływających na rozwój przedsiębiorstw świadczących usługi noclegowe i gastronomiczne

\begin{tabular}{|l|c|c|c|c|c|}
\hline Czynniki wpływające na rozwój przedsiębiorstw & \multicolumn{4}{|c|}{ Obszar } & \multirow{2}{*}{ Ogół } \\
\cline { 2 - 5 } świadczących usługi noclegowe i gastronomiczne $^{\prime}$ & 1 & 2 & 3 & 4 & \\
\hline System podatkowy & 3,86 & $4,32^{\mathrm{a}}$ & 4,08 & $3,75^{\mathrm{a}}$ & 3,99 \\
\hline Dostępność kapitału & 3,71 & 3,73 & 3,77 & 3,69 & 3,74 \\
\hline Odpowiednia polityka rządu & $3,82^{\mathrm{a}}$ & 4,18 & $4,14^{\mathrm{a}}$ & 3,96 & 4,03 \\
\hline Odpowiednia polityka samorządu & 3,53 & 3,45 & 3,58 & 3,45 & 3,54 \\
\hline Promocja gminy, powiatu & 3,37 & 3,14 & 3,28 & 3,31 & 3,30 \\
\hline Programy pomocowe UE & 2,93 & 3,05 & 2,62 & 2,78 & 2,75 \\
\hline $\begin{array}{l}\text { Pomoc organizacji wspierających rozwój turystyki } \\
\text { i przedsiębiorczości }\end{array}$ & $3,28^{\mathrm{a}}$ & 3,14 & $2,93^{\mathrm{a}}$ & 3,12 & 3,06 \\
\hline
\end{tabular}

a - wskazuje na istotną różnicę pomiędzy dana parą średnich $(p<0,05)$.

Oznaczenia: obszar 1 - miasta: Lublin, Zamość; obszar 2 - miasta: Biała Podlaska, Chełm; obszar 3 - powiaty: janowski, łukowski, opolski, parczewski, tomaszowski; obszar 4 - powiaty: puławski, włodawski.

Liczby odpowiadają wartościom skali 1-5, gdzie 1 - brak potrzeby zmiany, 5 - bardzo duża potrzeba zmiany.

Źródło: Opracowanie własne na podstawie badań ankietowych.

Przedstawione wyżej wyniki badań wskazują że istniejące uwarunkowania otoczenia instytucjonalno-systemowego w znaczący sposób odbiegają od stanu pożądanego. 


\section{Podsumowanie i wnioski}

Przeprowadzone badania na temat instytucjonalno-systemowych uwarunkowań rozwoju przedsiębiorstw noclegowych i gastronomicznych w województwie lubelskim pozwoliły stwierdzić, że w opinii przedsiębiorców:

- państwo niedostatecznie wywiązuję się z roli kreatora sprzyjających rozwiązań systemowych, które ułatwiałyby prowadzenie działalności gospodarczej;

- obecnie funkcjonujący system podatkowy w zdecydowany sposób utrudnia rozwój większości obiektów noclegowych oraz zakładów i punktów gastronomicznych na terenie województwa lubelskiego, szczególnie rzutuje na położenie podmiotów gospodarczych prowadzących swoją działalność na terenie powiatów ziemskich;

- dostępność kapitału nie stanowi obecnie największego problemu w kontekście rozwijania działalności na rynku usług noclegowych i gastronomicznych; może to wynikać z finansowania w dużej mierze funkcjonowania mikroprzedsiębiorstw ze środków własnych;

- poprawnie realizują swoje zadania organizacje wspierające rozwój turystyki i przedsiębiorczości, ich stosunkowo wysoka, choć tylko umiarkowana ocena wynika często z doświadczeń osobistych przedsiębiorców;

- programy pomocowe Unii Europejskiej adresowane do mikroprzedsiębiorców z rynku turystycznego wydają się być znane i pozytywnie postrzegane tylko przez niewielką część ich potencjalnych beneficjentów, sytuację powinny poprawić zakrojone na szerszą skalę $\mathrm{w}$ regionie województwa lubelskiego akcje jednostek otoczenia biznesu popularyzujące możliwość wykorzystania środków unijnych na rozwój działalności gospodarczej;

- większość przedsiębiorców nie potrafi zająć konkretnego stanowiska w kwestiach oceny realizowanej polityki samorządu, promocji gminy i powiatu, programów pomocowych UE, co może wskazywać na niski poziom świadomości respondentów odnośnie możliwości rozwojowych wynikających $\mathrm{z}$ istniejącego otoczenia instytucjonalno-systemowego.

Rozwój podmiotów gospodarczych funkcjonujących na rynku usług noclegowych i gastronomicznych jest uzależniony od dokonania właściwych zmian uwarunkowań życia gospodarczego na szczeblach centralnym oraz lokalnym. Jednak w odniesieniu do sukcesu rynkowego wielkie znaczenie mają wiedza i intuicja samych przedsiębiorców, którzy powinni w maksymalnym stopniu wykorzystywać istniejące już dziś szanse na rozwój swojej działalności gospodarczej. Warunkiem jest tu stałe monitorowanie sytuacji w otoczeniu instytucjonalno-systemowym przedsiębiorstw i podejmowanie właściwych decyzji. 


\title{
Literatura
}

ANGOWSKI M., 2010: Wpływ otoczenia na rozwój sektora matych i średnich przedsiębiorstw na obszarach wiejskich, Wydawnictwo Akademii Rolniczej w Lublinie, Lublin.

DRAB-KUROWSKA A., SOKÓŁ A., 2010: Małe i średnie przedsiębiorstwa wobec wyzwań rozwoju technologii XXI wieku, CeDeWu, Warszawa.

GRZEGORZEWSKA-MISCHKA E., 2009: Przedsiębiorca w gospodarce turystycznej, Wyższa Szkoła Turystyki i Hotelarstwa w Gdańsku, Gdańsk.

LICHNIAK I. (red.), 2011: Determinanty rozwoju przedsiębiorczości w Polsce, Oficyna Wydawnicza Szkoła Główna Handlowa w Warszawie, Warszawa.

SOBCZYK G. (red.), 1995: Funkcjonowanie matych firm $w$ warunkach zmian systemowych, Wydawnictwo Uniwersytetu Marii Curie-Skłodowskiej w Lublinie, Lublin.

WALICA H., 2004: Projektowanie podjęcia i/lub rozszerzenia działalności gospodarczej przez małe i średnie przedsiębiorstwa, [w:] A. Nehring (red.), Uwarunkowania rozwoju i konkurencyjności przedsiębiorstw, Wyższa Szkoła Biznesu w Dąbrowie Górniczej, Dąbrowa Górnicza.

http://www.stat.gov.pl/

\section{Institutional - systemic conditions for the development of providers of gastronomic and accommodation services in Lublin region - the current and desirable state}

\begin{abstract}
The purpose of this article is to determine the effect of institutional - systemic environment for the development of accommodation facilities and gastronomic establishments and catering points operating in the Lublin region. The research conducted in 11 districts on a sample of 317 operators in the spring of 2013 also enabled the identification of the needs of entrepreneurs in the field of desirable changes in institutional-systemic environment in the future. The greatest difficulty in running a gastronomic and accommodation business is the current policy of the government, which does not sufficiently take into account the interests of the tourism industry. The functioning tax system is perceived by respondents as an unfavorable one. The aid organizations supporting the development of tourism and entrepreneurship, and the availability of EU aid programs are the most conducive growth factors. Businessmen feel the urge to change the existing tax system and to improve the situation regarding the pos-
\end{abstract}


88

sibility and easiness of raising capital from external financing sources. Local governments while preparing future strategies of socio-economic development should take into priorities for the development of tourism and entrepreneurship. 